\title{
A report on the postoperative outcome of MylOL603YP implantation in Hospital Melaka
}

Khavigpriyaa Kalaichelvam, Lai Yin Peng, Norfadzillah Abdul Jalil, Raja Norliza Raja Omar

Department of Ophthalmology, Hospital Melaka, Ministry of Health, Malaysia

\section{Abstract}

This study reports the experience and outcomes of a new monofocal intraocular lens (IOL) by the name of MyIOL603YP. The performance of MylOL603YP over a 2-month follow-up period from June to December 2016 was assessed.

Twenty-nine patients, one eye from each patient, were recruited by convenience sampling method and were evaluated prospectively. Patients who were eligible to receive welfare IOLs were chosen. Detailed, preoperative examination was done, and the surgical procedure was the same for all, which was phacoemulsification with MylOL603YP implantation with random surgeon selection. Intraoperative complications were recorded by the surgeon. Postoperative examination was done during follow-up at one week and two months post cataract operation.

Results were obtained from 22 eyes ( 7 defaulted). Twenty eyes (84.7\%) achieved an unaided postoperative visual acuity of $6 / 12$ or better. There were no intraoperative or postoperative complications. There was no reported inflammation two months after cataract surgery with implantation of MylOL603YP and no posterior capsule opacification was reported.

Keywords: acrylic, hydrophobic, monofocal, MylOL603YP, preloaded, performance, visual outcomes 


\section{Laporan mengenai hasil pasca pembedahan implantasi MyIOL603YP di Hospital Melaka}

\section{Abstrak}

Kajian ini melaporkan pengalaman dan hasil pembedahan katarak setelah implantasi kanta intraokular (IOL) monofokal rekaan baru yang bernama MyIOL603YP. Prestasi MyIOL603YP dalam tempoh susulan 2 bulan dari Jun hingga Disember 2016 telah dinilai.

Dua puluh sembilan pesakit, satu mata dari setiap pesakit, telah diambil oleh kaedah pensampelan mudah dan dinilai secara prospektif. Pesakit yang layak menerima IOL kebajikan dipilih. Pemeriksaan terperinci, pra pembedahan dilakukan, dan prosedur pembedahan adalah sama untuk semua, yang merupakan fakoemulsifikasi dengan implantasi MyIOL603YP dengan pemilihan pakar bedah secara rawak. Komplikasi intraoperatif direkodkan oleh pakar bedah. Pemeriksaan pasca pembedahan dilakukan semasa susulan pada satu minggu dan dua bulan selepas pembedahan katarak.

Keputusan diperoleh daripada 22 mata (7 gagal). Dua puluh mata (84.7\%) mencapai tahap ketajaman penglihatan tanpa refraksi selepas pembedahan 6/12 atau lebih baik. Tiada komplikasi semasa atauselepas pembedahan direkodkan. Tidak ada keradangan yang dilaporkan dua bulan selepas pembedahan katarak dengan implantasi MyIOL603YP dan tiada kekeruhan pada kapsul posterior dilaporkan.

Kata kunci: akrilik, hidrofobik, monofokal, MyIOL603YP, pramuat, prestasi, hasil visual

\section{Introduction}

Cataract is defined as opacity within the clear lens of the eye. It is the major factor contributing to reversible blindness worldwide. ${ }^{1}$ It affects around 18 million people around the globe; this number accounts for $51 \%$ of the population. ${ }^{2}$ Based on the Malaysian National Eye Survey II 2014 population, cataract is the main cause of blindness (58\%) and low vision (68\%). Ministry of Health Malaysia (MOH) reported more than a two-fold raise in the number of cataract surgeries being performed from 2002 to 2011. Most MOH hospitals perform around 500 to 1000 cataract surgeries a year. ${ }^{2}$ Recently, there has also been a shift in preference in the type of cataract surgery performed, from extracapsular cataract extraction (ECCE) to phacoemulsification. This popular method, which accounts for more than $50 \%$ of cataract surgeries, brings a parallel change to the preferred intraocular lens (IOL) type and materials used. ${ }^{2}$ 
With the new advancement of technology, new IOLs are being created with different designs and additional features. Biocompatibility of an IOL is affected by a few factors, mainly patient factors, surgeon factors, and the IOL itself. ${ }^{3}$ The design and material of the IOL plays a major role in influencing the outcome, such as postoperative inflammation and posterior capsule opacification (PCO), which occurs in up to $50 \%$ of cases. ${ }^{4}$ Nishi et al. found that lenses with square edges inhibited lens epithelial cell migration and PCO formation. ${ }^{5} \mathrm{~A}$ study comparing different materials used with the same lens design supports the theory that hydrophobic acrylic IOLs lead to significantly less PCO in a two-year follow-up period compared to hydrophilic acrylic IOLs. ${ }^{6}$ As for postoperative inflammation, an IOL with excellent biocompatibility, such as an acrylic lens, incites lower rates of cellular deposits, thus reducing inflammation. ${ }^{7}$

On the other hand, manufacturing details concerning folding, implantation, and affordability of the lens also are important factors to consider. In higher income countries, phacoemulsification followed by implantation of a foldable IOL is the procedure of choice. It provides better visual outcomes and less astigmatism due to the small incision. ${ }^{8}$ However, a randomized controlled trial showed that implanting an inexpensive, rigid IOL after phacoemulsification gives comparable visual outcomes to the more expensive foldable IOL, providing surgeons are equally proficient at sclero-corneal tunnel and clear-corneal incisions. ${ }^{9}$

We report the initial experience and outcomes of the newly manufactured $\mathrm{IOL}$, MyIOL603YP. It is a yellow, aspheric, equiconvex, hydrophobic, preloaded lens with a square-edge design and zero-degree angulation. It is made of acrylic material with an overall diameter of $12.5 \mathrm{~mm}$ and an optic diameter of $6.0 \mathrm{~mm}$. The incision size is $2.4 \mathrm{~mm}$. Its power ranges from $5.0 \mathrm{D}$ to $30.0 \mathrm{D}$ with 0.5 increments. Its refractive index is 1.4933 and the A-constant is $118.0 / 118$.3. It can be implanted in the sulcus.

\section{Materials and Methods}

This is a prospective study to evaluate visual outcomes after cataract surgery with implantation of the MYIOL603YP over a two-month follow-up period from June to December 2016 in Hospital Melaka. Hospital Melaka is a secondary hospital situated on the West coast of Peninsular Malaysia.

This study enrolled 29 patients, 1 eye from each patient. Demographic information, pre- and postoperative visual acuity, diagnosis of unoperated eye, comorbidities in the operated eye, intra- and postoperative complications, postoperative inflammation, and postoperative formation of PCO were recorded.

Adult patients with visually significant cataracts were chosen via convenience sampling. Patients who were eligible to receive welfare IOL were chosen after being assessed by the social welfare department. Preoperative examination included vision, refraction, keratometry, slit-lamp biomicroscopy, tonometry, and detailed 
fundus examination. Informed consent was obtained from all patients undergoing cataract surgery.

Biometry calculation was done using immersion (Alcon, Fort Worth, TX, USA) and IOL Master (Zeiss, Oberkochen, Germany). The surgical procedure was the same for all, which was phacoemulsification with MylOL603YP implantation with random surgeon selection. Any intraoperative complications, specifically IOL-related complications, were recorded by the surgeon. Postoperative examination included vision testing, refraction, slit-lamp biomicroscopy, tonometry, and fundus examination. Follow-up was done at one week and two months post cataract operation. Subjects were evaluated for visual acuity and any postoperative complications during each follow up.

The performance endpoints were best spectacle-corrected visual acuity (BSCVA) and intraoperative and/or postoperative IOL-related complications. Results of the performance endpoints following implantation of MyIOL603YP were compared to the United States Food and Drug Administration (FDA) grid values of a historical population. ${ }^{10}$ This study protocol was registered with the National Medical Research Register.

\section{Results}

Out of the 29 eyes that were recruited, 7 patients defaulted follow up; results were obtained from 22 eyes. Their ages ranged from 48-83 years with a mean age of 63 years. Of these 22 patients, 4 (18.2\%) were male, and 18 (81.8\%) were female. There

\section{Preoperative and Postoperative unaided visual acuity range}

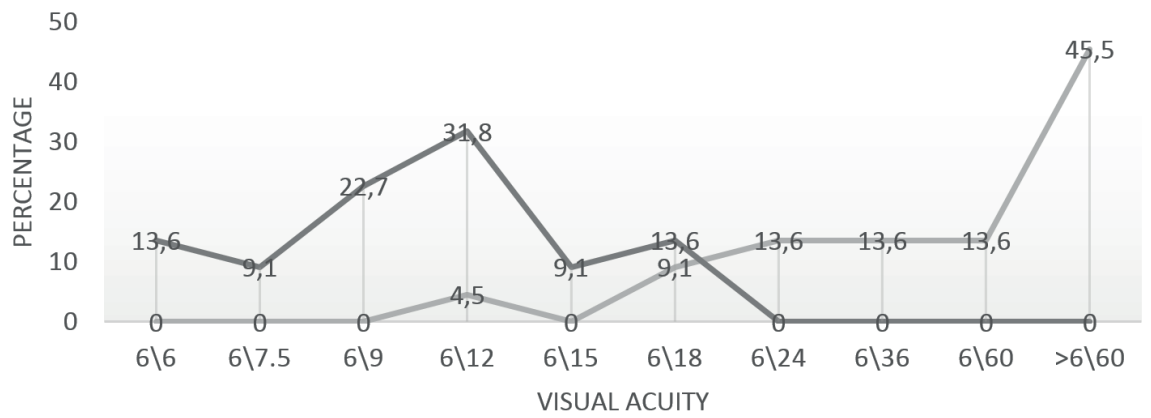

Preoperative Percentage ( \%)

Postoperative Percentage (\%)

Fig. 1. Preoperative and Postoperative unaided visual acuity range 
Table 1. Postoperative best spectacle-corrected visual acuity by age group

\begin{tabular}{|l|l|l|l|l|}
\hline \multirow{2}{*}{ Age group } & \multirow{2}{*}{ Total eyes } & \multicolumn{3}{|l|}{$\mathbf{6 / 1 2}$ or better } \\
\cline { 3 - 5 } & & Number of eyes & Distribution (\%) & FDA grid (\%) \\
\hline$<60$ years old & 8 & 8 & 100.0 & 98.5 \\
\hline $60-69$ years old & 9 & 8 & 88.9 & 96.5 \\
\hline $70-79$ years old & 3 & 3 & 100.0 & 97.5 \\
\hline$>80$ years old & 2 & 1 & 50.0 & 94.8 \\
\hline Total & 22 & 20 & 84.7 & 96.7 \\
\hline
\end{tabular}

were six Malay, five Chinese, ten Indian, and one Eurasian patient. Preoperative vision of recruited patients ranged from $6 / 12$ to worse than $6 / 60$, with the major percentage being from vision worse than $6 / 60$. Of the eyes recruited, $77 \%$ achieved unaided postoperative visual acuity of $6 / 12$ or better (Fig. 1). Postoperative BSCVA was analysed by age group and compared with the FDA grid values of a historic population. Patients from age group $<60$ years old and $70-79$ years old yielded very satisfactory results. Two eyes did not achieve $6 / 12$ or better vision postoperatively (Table 1). There were no intra- or postoperative complications. This results in a satisfactory outcome considering the small sample size of this study. There was no reported inflammation two months after cataract surgery with implantation of MylOL603YP. PCO was not reported in any of the studied eyes at two months post cataract surgery with MyIOL603YP implantation.

\section{Discussion}

Cataract surgery is widely perceived to be a safe and successful procedure. Better visual outcomes and lower complication rates were reported with phacoemulsification compared to ECCE. ${ }^{11}$

In this study, it was found that the MyIOL603YP IOL presents satisfactory visual outcomes. This result was compared to the FDA grid values. The FDA has established the BSCVA values and adverse-event rates for a historical control population subjected to IOL implantation.

Considering the small study sample size in comparison to the clinical studies that yielded the FDA grid results, the visual outcomes exceed the FDA grid results for BSCVA in the age group $<60$ years old and 70-79 years old. One patient from age group 60-69 years old had a BSCVA of 6/15 due to an underlying epiretinal membrane, and 1 patient from age group $>80$ years old had a BSCVA of 6/15 due to ocular surface disorder. BSCVA in pooled subjects was $6 / 12$ or better in $84.7 \%$ of eyes. This is lower than the expected value of FDA grid percentage, which is $96.7 \%$. 
However, a UK national cataract survey resulted in $86 \%$ with vision $6 / 12$ or better. ${ }^{12}$ According to the Swedish National Cataract Register, cataract surgery resulted in $84 \%$ with vision $6 / 12$ or better. ${ }^{13}$ There were no reported intra- or postoperative complications. This also exceeds the FDA grid values.

IOL biocompatibility can be divided into uveal (inflammatory cell attachment) and capsular (anterior capsular fibrosis, PCO). As for postoperative inflammation, only 1 patient had acute, postoperative inflammation of cells $2+$ (mild) 1 week post surgery. Acute, postoperative inflammation is defined as an anterior chamber reaction equivalent to, or more than, $2+$ cells, and flare or fibrin formation in the anterior chamber. ${ }^{14}$ This later resolved at the two-month follow up with regular steroid therapy.

It was also observed that there was an absence of PCO until two months post operation. Wainsztein et al. observed in their study that mature cataracts had a significantly lower tendency to produce PCO than other cataract types. ${ }^{15}$ Spalton, in his review article, demonstrated that PCO is the commonest complication of cataract surgery, occurring in up to $50 \%$ of patients 2-3 years after surgery. ${ }^{16}$ Hydrophilic materials are generally considered to have a better uveal biocompatibility profile in comparison to hydrophobic materials, but with present IOL designs the latter may have a better performance in preventing PCO..$^{17,18}$

Overall, this study indicates that MylOL603YP preloaded, hydrophobic, acrylic $\mathrm{IOL}$ is generally efficacious and relatively safe based on an outcome observed at two months post operation. ${ }^{1}$

\section{References}

1. Pascolini D, Mariotti SP. Global estimates of visual impairment: 2010. Br J Ophthalmol. 2012;96:614618.

2. Lee MY, Goh PP, Salowi MA, Adnan TH, Ismail M. The Malaysian cataract surgery registry: cataract surgery practice pattern. Asia Pac J Ophthalmol (Phila). 2014;3(6):343-347.

3. Huang Q, Cheng GP, Chiu K, Wang GQ. Surface modification of intraocular lenses. Chin Med J (Engl). 2016;129(2):206-214.

4. Apple DJ, Solomon KD, Tetz MR, et al. Posterior capsule opacification. Surv Ophthalmol. 1992;37:73116.

5. Nishi O, Nishi K, Wickström K. Preventing lens epithelial cell migration using intraocular lenses with sharp rectangular edges. J Cataract Refract Surg. 2000;26:1543-9.

6. Li Y, Wang J, Chen Z, Tang X. Effect of hydrophobic acrylic versus hydrophilic acrylic intraocular lens on posterior capsule opacification: meta-analysis. PLoS One. 2013;8(11):e77864.

7. Ravalico G, Baccara F, Lovisato A, Tognetto D. Postoperative cellular reaction on various intraocular lens materials. Ophthalmology. 1997;104(7):1084-1091.

8. Riaz Y, Mehta JS, Wormald R, et al. Surgical interventions for age-related cataract. Cochrane Database Syst Rev. 2006. doi:10.1002/14651858.CD001323.pub2. 
9. Hennig A, Singh S, Winter I, Yorston D. Can phaco be a cost-effective solution to cataract blindness? Costs and outcomes in Nepal. Eye (Lond). 2010;24(6).

10. Stark WJ, Worthen DM, Holladay JT, et al. The FDA report on intraocular lenses. Aust J of Ophthalmol. 1984;12(1):61-69.

11. de Silva SR, Riaz Y, Evans JR. Phacoemulsification with posterior chamber intraocular lens versus extracapsular cataract extraction (ECCE) with posterior chamber intraocular lens for age-related cataract. Cochrane Database Syst Rev. 2014. doi:10.1002/14651858.CD008812.pub2.

12. Desai P, Minassian DC, Reidy A. National cataract surgery survey 1997-8: a report of the results of the clinical outcomes. Br J Ophthalmol. 1999;83:1336-1340.

13. Lundstrom M, Stenevi U, Thorburn W. The Swedish national cataract register: A 9-year review. Acta Ophthalmol Scand. 2002;80:248-257.

14. Mohammadpour M, Jafarinasab MR, Javadi MA. Outcomes of acute postoperative inflammation after cataract surgery. Eur J Ophthalmol. 2007;17(1):20-8.

15. Argento C, Nunez E, Wainsztein R. Incidence of postoperative posterior capsular opacification with types of senile cataracts. J Cataract Refract Surg. 1992;18(6):586-8.

16. Spalton DJ. Posterior capsular opacification after cataract surgery. Eye (Lond). 1999;(Pt 3b):489-492.

17. Hayashi K, Hayashi H. Posterior capsule opacification after implantation of a hydrogel intraocular lens. Br J Ophthalmol. 2004;88(2):182-5.

18. Hollick EJ, Spalton DJ, Ursell PG, Meacock WR, Barman SA, Boyce JF. Posterior capsular opacification with hydrogel, polymethylmethacrylate, and silicone intraocular lenses: two-year results of a randomized prospective trial. Am J Ophthalmol. 2000;129(5):577-84. 